\title{
Budidaya Tanaman Hortikultura Memanfaatkan Lahan Pekarangan di Bunaken Manado
}

\author{
Ernest Hanny Sakul ${ }^{1}$, Revolson Alexius Mege ${ }^{2}$, Jacklin Stella Salome Manoppo ${ }^{3}$ \\ 1,2,3 Jurusan Biologi, Fakultas MIPA, Universitas Negeri Manado
}

\begin{abstract}
Bunaken Island which is shaped like the crescent, has an area of 696.8 ha and is a park conservation area national sea in North Sulawesi. Bunaken Island has two villages, first, Bunaken Village, the administrative area of up to Parigi Headland and Siladen Island. Then the second village is Alungbanua Village. Based on the survey results in the village of Bunaken- Parigi Headland, it was known that there are still many yards that are still not used for planting horticultural crops that can provide a food source for family. In addition, it was found that there were still many pigs released wildly by the community and produced large amounts of pig manure. Parigi Headland people have the potential to develop group and family businesses in agriculture, but still have limitations in developing farming technology, making and using organic fertilizers, and producing organic pesticides. PKM Horticultural Crop Cultivation Utilizing Yard Land in Bunaken Manado aims to train communities and families in the village of Bunaken-Parigi Headland to be able to utilize their yard and increase the quantity and quality of production of horticultural crops in the form of chili, tomatoes and vegetables. Furtheremore, it aims to guide and train the community so they can produce their own organic fertilizer as a result of fermentation of livestock manure. The results obtained were 1) an increase in public understanding of the importance of using yard land as a place of farming with high economic value such as chili, 2) results obtained by the early harvest chilies weight ranged from 0.50 to $1.10 \mathrm{~kg}$ per plant in the raised beds, and the weight of chilies grown in polybags have a range of 0.40 to 0.95 $\mathrm{kg}$ per plant, 3) organic fertilizer fermented manure waste using biological agents effective microorganism (EM4) was gained, and 4) the construction of the maintenance enclosure for pigs.
\end{abstract}

Keywords: organic fertilizer, cayenne pepper, Parigi Headland, idle land

\section{PENDAHULUAN}

\section{A. Analisis Situasi}

Secara geografis Pulau Bunaken terletak di Teluk Manado dengan di posisi sebelah barat ada Pulau Manado Tua sebelah Timur Pulau Siladen dan disebelah utara Pulau Nain dan Mantehage. Kebanyakan masyarakat hidup dari mata pencarian nelayan dengan mengandalkan alat tangkap tradisional seperti Funae, Pelang, Katinting dan Londe.

Pulau Bunaken yang berbentuk seperti bulan sabit itu, memiliki luas 696,8 ha adalah kawasan konservasi taman nasional laut di Sulawesi Utara. Di Pulau Bunaken terdapat dua desa, Pertama, Desa Bunaken dengan wilayah administrasi hingga ke tanjung parigi dan pulau siladen. Kedua, Desa Alungbanua.

Kelompok Tani-Ternak Desa Bunaken-Tanjung parigi yang beranggotakan 6 orang dan dipimpin oleh Bapak Jonathan Mangensiga adalah salah satu kelompok tani dan nelayan yang produktif secara ekonomi dan saat ini masih berusaha mengembangkan usaha nelayannya dan bertani tanaman hortikultura guna meningkatkan income yaitu cabai.

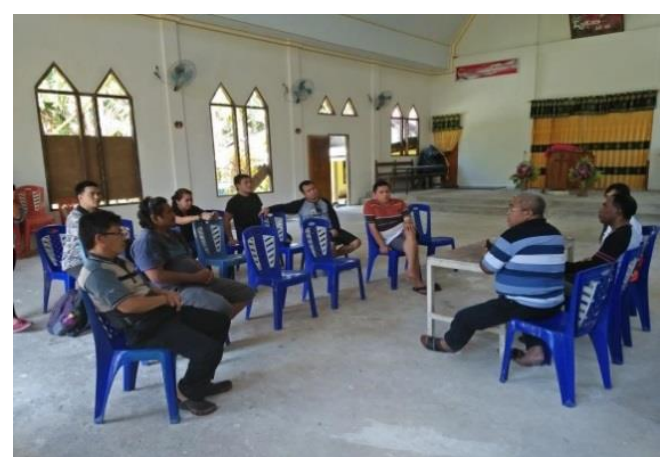

Gambar 1. Diskusi bersama Kelompok Tani Ternak Desa Bunaken Tanjung Parigi

Potensi desa ini untuk pengembangan desa hortikultura khususnya tanaman pangan yang menopang gizi masyarakat, keluarga-keluarga di 
setiap dusun atau jaga, sangatlah besar dan memberikan peluang yang nyata untuk peningkatan finansial keluarga para petani. Hal ini dibuktikan dengan hampir $80 \%$ pekerjaan utama warga desa ini adalah bertani baik tanaman palawija maupun tanaman hortikultura dan sisanya sekitar berprofesi sebagai Pegawai Negeri Sipil, Pegawai Swasta dan Wiraswasta.

Kenyataan di lapangan berdasarkan hasil survey awal di Desa Bunaken - Tanjung parigi, selain masih banyaknya pekarangan atau lahan tidur yang tidak dioptimalkan oleh masyarakat, ternyata banyak juga populasi babi hitam yang tidak dikurung (dilepas liar) sehingga memicu bertumpuknya kotoran dari hewan tersebut.

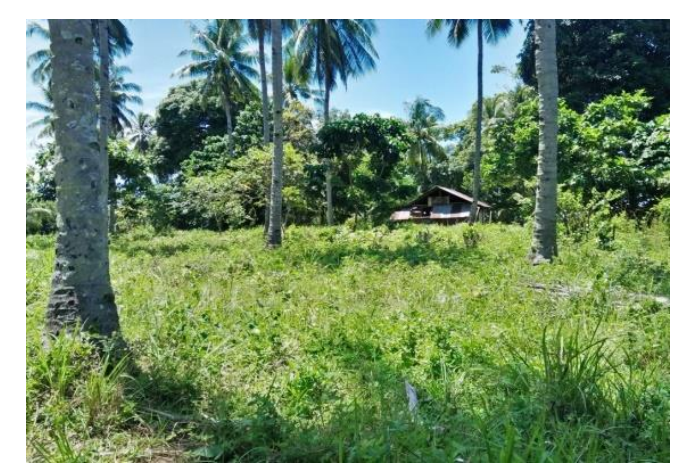

Gambar 2. Lahan pekarangan yang belum dimanfaatkan

Lahan tidur adalah lahan yang tidak atau belum produktif digunakan oleh masyarakat, sehingga perlu dikelola dengan baik untuk menghasilkan hasil yang baik. Pemanfaatan lahan tidur dan limbah organik didaerah perkotaan maupun pedesaan merupakan sebuah peluang usaha untuk meningkatkan kesejahteraan masyarakat. Jika tidak dikelola dengan baik, lahan tidur atau pekarangan yang tidak diolah, akan terbiar dengan percuma dan tidak memiliki nilai ekonomis yang tinggi, begitu juga sejumlah limbah organik yang dihasilkan dari berbagai macam tempat. Sejalan dengan perkembangan ilmu pengetahuan dan teknologi, sampah dapat diolah sedemikian rupa sehingga menjadi barang yang bermanfaat dan menguntungkan secara ekonomis (Manoppo et al., 2018).

Teknologi yang dapat digunakan dalam penanganan masalah sampah antara lain adalah pemanfaatan mikroorganisme seperti Effective
Microorganism 4 (EM4) sebagai upaya untuk mempercepat proses dekomposisi sampah khususnya sampah organik menjadi pupuk organik. Pupuk organik merupakan hasil akhir dan atau hasil antara dari perubahan atau peruraian bagian dan sisa-sisa tanaman dan hewan, misalnya bungkil, guano, tepung tulang, limbah kotoran ternak dan jenis limbah lainnya (Santika, 2017).

Pupuk organik merupakan pupuk yang terbuat dari bahan-bahan organik yang didegradasikan secara organik. Sumber bahan baku organik ini dapat diperoleh dari bermacam-macam sumber, seperti : kotoran ternak, sampah rumah tangga non sintetis, limbah-limbah makanan/minuman, dan lain-lain. Biasanya untuk membuat pupuk organik ini, ditambahkan larutan mikroorganisme yang membantu mempercepat proses pendegradasian (Manoppo, 2017).

\section{B. Permasalahan Mitra}

Masyarakat Desa Bunaken Tanjung Parigi memiliki potensi yang baik dalam mengembangkan usaha keluarga di bidang pertanian skala kecil dengan memanfaatkan lahan pekarangan rumah yang besar dan belum diefektifkan. Masyarakat masih memiliki keterbatasan dalam pengembangan teknologi bercocok tanam, penggunaan pupuk organik dan penggunaan pestisida organik.

Di Desa Bunaken Tanjung Parigi, hasil observasi langsung di lapangan, ditemukan banyak limbah peternakan seperti kotoran ternak babi. Limbah tersebut jika tidak dikelola dengan baik akan memberikan potensi kuat dalam proses pencemaran lingkungan, sementara itu pengetahuan masyarakat desa dirasakan masih kurang dalam mengolah limbah kotoran babi, sehingga terkadang kotoran tersebut dibiarkan secara bebas, tidak ada proses penanganan limbah dan memiliki potensi mencemari lingkungan disekitarnya bahkan mengancam kesehatan lingkungan desa tersebut.

Oleh karena itu dibutuhkan aplikasi teknologi yang dapat digunakan dalam penanganan masalah sampah atau limbah kotoran ternak tersebut, antara lain adalah pemanfaatan mikroorganisme sebagai upaya untuk mempercepat proses dekomposisi limbah organik menjadi pupuk organik. 
Penggunaan pupuk organik dapat menjadi bahan alternatif untuk mengurangi penggunaan pupuk buatan, karena pupuk organik mengandung unsur hara yang lengkap, yang berasal dari pelapukan atau sisa dari makhluk hidup seperti pupuk hijau, pupuk kandang dan kompos (Murbandono, 2014).

Pupuk organik hasil fermentasi inilah yang akan digunakan dalam bedengan maupun polibag yang telah disiapkan oleh warga masyarakat, untuk dimanfaatkan dalam bercocok tanam beberapa tanaman hortikultura seperti cabai, tomat, daun bawang, sayur-sayuran seperti sawi, pak-choy dan lain sebagainya.

\section{Solusi dan Target Luaran}

\section{Tujuan kegiatan}

Sesuai dengan rencana kegiatan, maka tujuan yang menjadi target dalam pelaksanaan kegiatan program kemitraan masyarakat ini adalah:

a. Membimbing dan melatih masyarakat untuk dapat memproduksi pupuk hayati hasil fermentasi limbah kotoran babi dengan menggunakan Effective Microorganism ( $\left(\mathrm{EM}_{4}\right)$.

b. Membimbing dan melatih masyarakat untuk bisa memproduksi pestisida nabati dari ekstrak tumbuhan lokal-

c. Membimbing dan melatih masyarakat berupa teknik bercocok tanam, pengendalam hama terpadu yang baik.

d. Membimbing dan melatih masyarakat untuk dapat bercocok tanam dengan memanfaatkan lahan pekarangan di rumah mereka masingmasing.

2. Manfaat kegiatan

a. Kegiatan ini diharapkan dapat memberikan manfaat bagi masyarakat desa BunakenTanjung Parigi sehingga mampu mengaplikasikan penggunaan pupuk organik cair yang dikombinasikan dengan pupuk organik hasil fermentasi limbah kotoran ternak yang menggunakan agen hayati EM4, pestisida organik dalam meningkatkan kualitas tanaman cabai.

b. Bagi Unima, kegiatan ini adalah upaya perwujudan misi perguruan tinggi, terutama merealisasikan salah satu dari Tri Dharma Perguruan Tinggi, yaitu dharma pengabdian pada masyarakat.

3. Manfaat kegiatan

Berdasarkan data informasi yang telah diperoleh dari masyarakat desa (kelompok sasaran) yaitu Desa Bunaken-Tanjung Parigi, ternyata masyarakat membutuhkan program pelatihan guna meningkatkan pengetahuan dan keterampilan mereka dalam penggunaan pupuk organik cair dan pupuk organik hasil fermentasi limbah kotoran ayam. Bersamaan dengan pelaksanaan plot tersebut, dilaksanakan juga sharing ilmu dan pendampingan teknis budidaya cabai dengan varietas unggulan (varietas bara), seperti teknologi budidaya yang lebih ramah lingkungan berupa pembuatan pupuk kompos padat melalui teknik fermentasi dengan menggunakan agen hayati $\mathrm{EM}_{4}$ pada limbah kotoran babi, pelatihan teknik pemasangan mulsa plastik hitam perak dengan baik dan benar, serta pelatihan pembuatan pestisida organik (biopestisida) juga dikembangkan dalam pelatihan ini.

\section{METODE PELAKSANAAN}

Berdasarkan hasil identifikasi masalah dan potensi lahan pekarangan di desa Bunaken-Tanjung Parigi. Beberapa kegiatan yang berkaitan diantaranya adalah sebagai berikut:

a. Peningkatan kemampuan pemahaman masyarakat tentang betapa pentingnya memanfaatkan lahan pekarangan untuk ditanami dengan tanaman cabai, melalui presentasi, penyuluhan dan diskusi kelompok.

b. Pengenalan tentang pupuk organik dan teknik membuat pupuk organik berbasis kotoran limbah ternak yang akan difermentasi dengan menggunakan bakteri EM4.

c. Pelatihan khusus pembuatan bedengan, pemasangan mulsa plastik hitam perak, teknik pemupukan lanjutan dengan pupuk organik cair seperti DI grow dan pasca panen tanaman cabai.

d. Peningkatan kemampuan masyarakat desa dalam mengelola hewan ternak babi yang baik dan dikandangkan. Juga masyarakat mampu membuat pestisida sendiri. 
Adapun beberapa metode yang digunakan dalam kegiatan ini adalah:

a. Metode yang ditempuh adalah metode demonstrasi dan unjuk kerja secara langsung di lahan pekarangan masyarakat desa bunakentanjung parigi.

b. Metode penyuluhan kepada masyarakat tentang pencemaran lingkungan oleh limbah kotoran ayam, babi dan limbah rumah tangga, serta memperkenalkan cara-cara penanganan limbah kotoran ayam, babi dan limbah rumah tangga, sehingga menjadi produk yang berguna berupa pupuk organik hasil fermentasi.

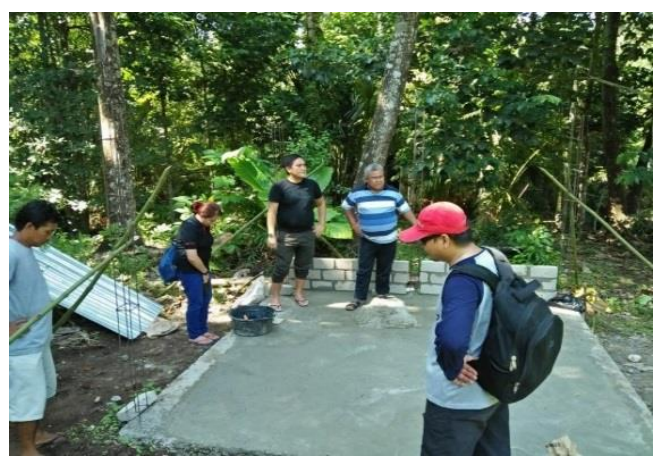

Gambar 3. Pembuatan kandang babi di lokasi PKM

c. Metode demonstrasi dan unjuk kerja secara langsung dalam pembuatan pupuk organik (kompos) dari limbah kotoran ayam, babi dan limbah rumah tangga dengan menggunakan agen-bioaktivator mikroorganisme (EM4).

d. Metode aplikasi di lapangan secara langsung dengan menanam dan memberikan pupuk organik pada tanaman cabai varietas Dewata F1 dan varietas Nirmala F1.

\section{HASIL DAN PEMBAHASAN}

\section{A. Pelaksanaan Program}

Kegiatan program kemitraan masyarakat dilaksanakan di Desa Bunaken-Tanjung Parigi Kota Manado. Yang menjadi sasaran pelaksanaan kegiatan program kemitraan ini adalah kelompok masyarakat desa tergabung dalam kelompok tani ternak.

Gambaran IPTEK yang telah dilaksanakan pada mitra kelompok tani ternak Desa Bunaken-Tanjung parigi adalah:
1. Teknik pengolahan lahan pekarangan yang akan dijadikan lokasi penanaman cabai, dilakukan dengan membuat bedengan yang berukuran lebar 1,5 meter dan jarak antar bedengan adalah $70 \mathrm{~cm}$ serta tinggi bedengan $30-40 \mathrm{~cm}$ dengan panjang bedengan 4 meter, yang disertai dengan pemupukan dasar berupa penambahan bahan organik hasil fermentasi seperti pupuk bokashi EM4. Kemudian lahan disiapkan 10 hari sebelum masa tanam, dengan tetap menggunakan kombinasi $80 \%$ pupuk organik dan $20 \%$ pupuk dasar jenis Urea, ZA, SP-36 dan KCL (Manoppo et al., 2018).

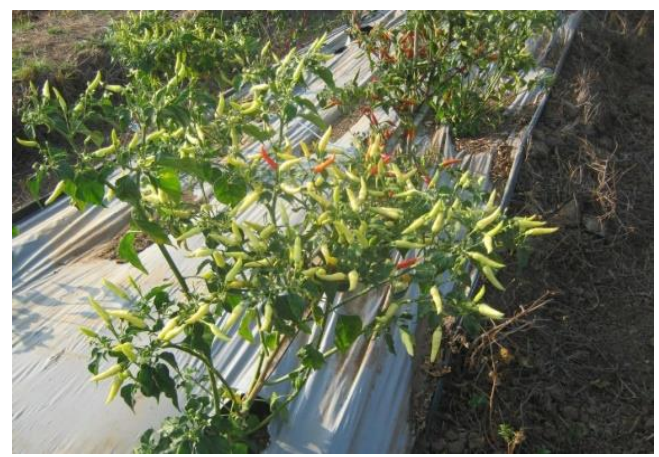

Gambar 4. Budidaya cabai rawit di lahan pekarangan

2. Teknik membuat pupuk organik bokashi dengan menggunakan Effective Microorganism (EM4) dalam mempercepat proses dekomposisi limbah kotoran babi.

3. Teknik penyemaian benih yang baik dan benar dengan menggunakan tray bibit maupun plastik semai dan campuran media semai jenis cocopeat. Benih dipelihara di screen house sederhana atau sungkup.

4. Teknik pengendalian hama terpadu dengan membuat biopestisida sendiri dari tanaman lokal yang berpotensi menjadi biopestisida seperti Pangi (Pangium edule) (Sakul, 2017; Manoppo \& Sakul, 2017).

5. Teknik pemasangan mulsa plastik hitam perak (MPHP), cara mengencangkan mulsa pada bedengan dan cara membuat lubang tempat menanam bibit pada mulsa. Juga teknik memasang ajir atau lanjaran (bambu penyokong) (Salaki \& Montong, 2017). 
6. Teknik pemeliharaan lanjutan untuk tanaman cabai sekaligus pemupukan dengan menggunakan pupuk organik cair DI.Grow Red dan Green dalam meningkatkan kualitas fase vegetatif dan generatif.

7. Teknik pasca panen tanaman cabai varietas nirmala (Manoppo et al., 2018).

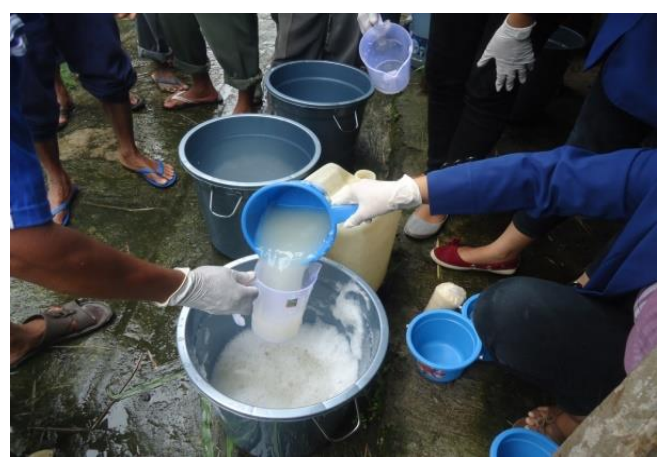

Gambar 5. Pembuatan pestisida organik

\section{B. Monitoring dan Evaluasi Program}

Monitoring dilaksanakan selama pelaksanaan kegiatan. Dilakukan minimal satu kali seminggu dengan memeriksa laporan kemajuan harian dari kedua kelompok tersebut.

Kegiatan monitoring turut dihadiri oleh ketua kelompok tani dan pimpinan/pemerintah desa bunaken-tanjung parigi yaitu Hukum Tua atau Lurah.

Evaluasi keterlaksanaan program kemitraan masyarakat dilakukan 3 kali yaitu evaluasi pada awal, pertengahan dan akhir pelaksanaan program. Metode evaluasi mencakup diskusi dan analisis hasil panen akhir, metode pemeliharaan dan hambatan yang diperoleh selama PKM berlangsung.

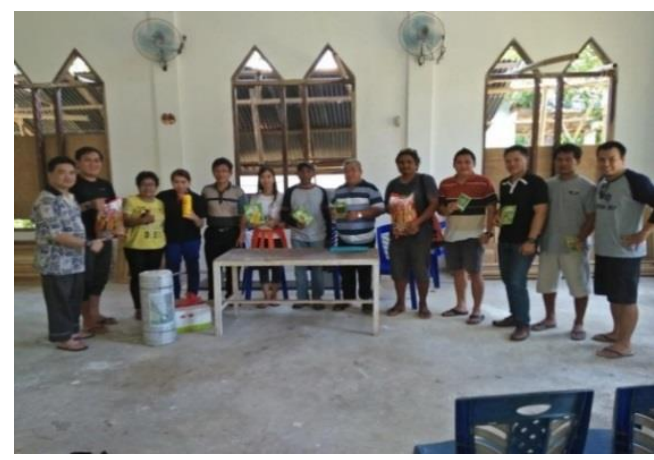

Gambar 6. Evaluasi dan serah terima alat dan bahan
Luaran Wajib yang telah dicapai berupa satu artikel hasil kegiatan PKM yang telah dipublikasikan pada media massa cetak dan media massa online yaitu:

1. Publikasi pada jurnal pengabdian masyarakat edisi September 2018 atau Prosiding pada Seminar Nasional PKM.

2. Publikasi Kegiatan PKM di Koran Harian Metro Manado.

3. Publikasi Kegiatan PKM di Koran Elektronik Kabar Manado

Luaran tambahan berupa HAKI (Hak Kekayaan Intelektual), sementara dalam proses pengurusan di Departemen Kehakiman dan HAM.

\section{KESIMPULAN}

a. Program Kemitraan Masyarakat Budidaya Tanaman Hortikultura Memanfaatkan Lahan Pekarangan Di Bunaken-Tanjung Parigi, pada kelompok tani-ternak telah memberikan dampak positif dalam peningkatan kualitas lahan pekarangan rumah masing-masing dan ketercukupan gizi keluarga dari tanaman hortikultura yang dikembangkan.

b. Masyarakat Desa Bunaken-Tanjung Parigi, pada akhirnya dapat mempraktekkan metode cara bercocok tanam yang baik dan benar, dalam meningkatkan hasil panen cabai dari segi kuantitas dan kualitas hasil cabai, seperti teknik membuat pupuk hayati berbasis fermentasi EM4, pengendalian hama terpadu menggunakan biopestisida.

c. Adanya peningkatan pemahaman masyarakat tentang pentingnya menggunakan lahan pekarangan sebagai tempat bercocok tanam yang bernilai ekonomis tinggi seperti cabai.

d. Hasil panen cabai yang diperoleh yaitu berat buah cabai berkisar $0,50-1,10 \mathrm{~kg}$ per tanaman di bedengan, dan berat buah cabai yang ditanam di polibag memiliki kisaran $0,40-0,95 \mathrm{~kg}$ per tanaman.

e. Dibangunnya kandang pemeliharaan untuk hewan ternak babi liar sehingga ternak babi dapat dipelihara dengan baik. 


\section{UCAPAN TERIMA KASIH}

Ucapan Terima Kasih Rektor Universitas Negeri Manado dan Ketua Lembaga Penelitian dan Pengabdian Masyarakat serta seluruh staf LPPM Universitas Negeri Manado yang telah memfasilitasi kegiatan dengan pendanaan lewat PNBP UNIMA 2018. Tak lupa juga diucapkan terima kasih kepada Hukum Tua/Lurah Desa BunakenTanjung Parigi dan Gembala KGPM Desa Bunaken-Tanjung Parigi.

\section{DAFTAR PUSTAKA}

Manoppo, J.S.S., and Ernest H. Sakul., 2017. Impact of Biomolluscicides Derived From Annona muricata, Pangium edule And Derris elliptica Extracts On Golden Apple Snail (Pomacea canaliculata Lamarck) Department of Biology, Faculty of Mathematics and Natural Sciences, State University of Manado, Indonesia, dalam Prosiding Seminar Nasional LPPM Universitas Negeri Manado, ISBN : 978-602-14701-1-4. http://repository.unima.ac.id/bitstream/123456789 /66/1/PROSIDING\%20SEMINAR\%20HASIL\%2 0PPM\%202017\%20Edit\%2013\%20Oktober\%20\% 281\%29.pdf.

Manoppo, J.S.S. 2017. Potential Extracts of Pangium edule Reinw and Derris elliptica Wallich as Botanical Molluscicides for Management of Golden Apple Snail Pomacea canaliculata Lamarck. Agrotech Journal. Universitas Sembilan Belas Nopember Kolaka.
Vol. 2, No. 2, November 2017 ISSN: 2548-5121 URL:http://usnsj.com/index.php/ATJ/article/view /2.2,14-20.

Manoppo, J.S.S, Ernest H. Sakul dan Marlina Karundeng, 2018. PKM Kelompok Tani Cabai Di Desa Paslaten Kecamatan Remboken Kabupaten Minahasa Propinsi Sulawesi Utara. Jurusan Biologi FMIPA Universitas Negeri Manado.

Murbandono ,HS. L. 2014. Membuat Kompos. Penerbit Penebar Swadaya. Jakarta.

Sakul, E.H., 2017. Impact of Botanical Insecticides Derived From Pangium edule Reinw And Annona muricata L. Seed Extracts on The "Gay Gantung" Diamondback Moth, Plutella xylostella $\boldsymbol{L}$. Agrotech Journal. Universitas Sembilan Belas Nopember Kolaka Vol. 2, No. 2, November 2017 ISSN: 2548-5121 URL:http://usnsj.com/index. $\mathrm{php/ATJ/article/view/2.2,14-20}$

Salaki, Ch dan Vivi Montong, 2017. Pemanfaatan Tanaman Penghasil Minyak Atsiri Serai Wangi (Andropogon nardus) Dan Lengkuas (Alpinia galangal) Sebagai Pestisida Nabati Untuk Mengendalikan Hama Utama Tanaman Cabai. dalam Proceeding Seminar Nasional Biologi XXIV 2017. "Penelitian,Bioprospeksi dan Pemanfaatan Berkelanjutan dari Keanekaragaman Hayati”. Perhimpunan Biologi Indonesia dan Universitas Sam Ratulangi Manado, Lion Hotel Plaza Manado. Bioling A.7. Artikel Pengabdian Pada Masyarakat. http://repo.unsrat.ac.id/2002/1/ ProsidingSemnasPBIManado2017_Upload.pdf

Santika, A. 2017. Agribisnis Cabai. Penebar Swadaya Jakarta. 